\title{
A SIMPLE METHOD FOR THE ESTIMATION OF TOTAL PROTEIN CONTENT OF PLASMA AND SERUM. II. THE ESTIMATION \\ OF TOTAL PROTEIN CONTENT OF HUMAN PLASMA AND SERUM BY THE USE OF THE FALLING DROP METHOD
}

\author{
By BENJAMIN M. KAGAN \\ (From the Department of Medicine, School of Medicine, Johns Hopkins University and \\ Hospital, Baltimore)
}

(Received for publication June 11, 1937)

An instrument for the accurate estimation of serum protein which has the simplicity of a hemoglobinometer has an obvious place in medicine. Peters and Van Slyke (1) have reviewed the many physical methods which have been tried and conclude that the specific gravity is the most accurate. They find the colorimetric method liable to errors up to 10 per cent. Moore and Van Slyke (2) found the relationship between the specific gravity and protein content of human heparinized plasma could be expressed by the equation of a straight line:

$$
P=343(G-1.0070)
$$

in which $P$ represents grams of protein per $100 \mathrm{cc}$. and $G$ the specific gravity. They found the maximum deviation from the value of total protein estimated by the gasometric method to be 0.6 gram per cent. Zozaya (3) found that the above formula did not give good results with human serum. Weech et al. (4) used dog's blood and demonstrated a linear relationship for serum and for heparinized plasma. They used the micro$\mathrm{Kjeldahl}$ as standard and claimed an even better correlation than Moore and Van Slyke. In all of these investigations, the specific gravity was determined by the use of pyknometers and delicate balances. Moore and Van Slyke found the falling drop method of Barbour and Hamilton (5) for specific gravity to give as good results as pyknometry, but because the method required the constant use of standards and nomograms, they gave it up. An analysis of the falling drop method which is used in this investigation and a comparison with that of Barbour and Hamilton is given in the first section of this paper (12).

\section{METHODS}

The specimens of blood were obtained by venepuncture from patients in the hospital and out- patient departments. Most of the patients were selected because they were known to have abnormalities in their blood proteins or in other blood constituents. Total serum protein was determined by the macro-Kjeldahl method using the methyl red-methylene blue indicator as described by Johnson and Green (6). Refractometric readings were done routinely. The results obtained by the latter method are better than those generally reported because an as yet unpublished correction factor is used which is based upon thousands of macro-Kjeldahl determinations. The specific gravity was determined by the falling drop method and represents the weight of serum at $25.0^{\circ} \mathrm{C}$. referred to the weight of the same volume of water at the same temperature. The correlation between total protein and specific gravity was determined by the method of least squares (7).

The chloride content was determined by the method of Van Slyke (1) and the cholesterol content by the method of Sackett (8). ${ }^{1}$

\section{RESULTS}

Serum. The results on 107 specimens of sera are plotted in Figure 1. The linear relationship may be expressed by the equation:

$$
P=345(G-1.0076) \text {, }
$$

where $P$ is the total grams of protein per $100 \mathrm{cc}$. of serum and $G$ the specific gravity $25^{\circ} / 25^{\circ} \mathrm{C}$. The mean deviation of total protein as estimated from this formula and that determined by macroKjeldahl was \pm 0.16 gram per cent. The greatest deviation was +0.48 . In the same sera, the mean deviation of the total protein value deter-

\footnotetext{
1 The chemical determinations and refractometry were done under the direction of Dr. Mary V. Buell, with the technical assistance of Miss Betsy Shirk.
} 


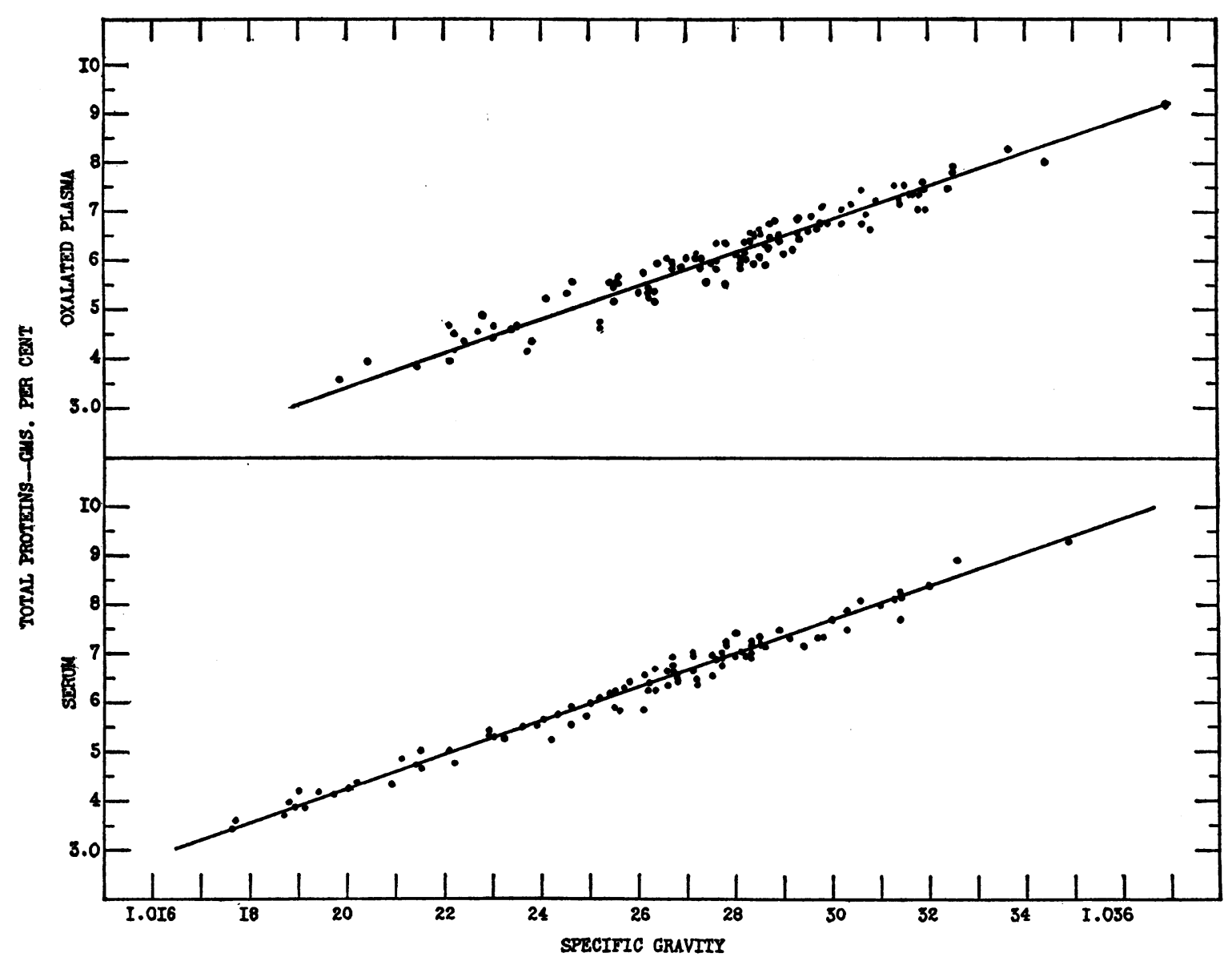

Fig. 1. Relation of Spectic Gravity to Total Protein Content of Plasma and Serum

mined by refractive index and that by $\mathrm{Kjeldahl}$ was \pm 0.37 and the greatest deviation -1.04 gram. In over 25 per cent of the specimens, the deviation of the estimation of refractive index from the Kjeldahl was more than 0.45 gram per cent.

Plasma. The plasma was prepared by drying 5 drops of 10 per cent potassium oxalate in bottles to which $10 \mathrm{cc}$. of blood was added. Such an amount of oxalate added to distilled water raises its specific gravity $0.0023,25^{\circ} / 25^{\circ} \mathrm{C}$. The results on 122 specimens of plasma are also plotted in Figure 1. The relationship may be expressed by the equation:

$$
P=340(G-1.0099) \text {. }
$$

The mean deviation of total protein as calculated from this formula and that determined by macro-Kjeldahl was \pm 0.23 . The greatest devia- tion was +0.59 . In the same plasma, the mean deviation of total protein estimated by refractometry and that by Kjeldahl was \pm 0.36 . The greatest deviation was +1.50 grams per cent. In 10 specimens, the difference was greater than 0.6 gram, and in 3 greater than 1.00 gram.

The estimation of total protein in plasma is not as accurate as in serum, but $10 \mathrm{cc}$. of blood were not always added to the same amount of oxalate and this probably accounts in large part for the difference. In addition, oxalate is known to withdraw a variable amount of water from the cells and so dilute the plasma.

\section{The effect of variations in the $A / G$ ratio}

On 79 of the total 229 specimens, the A/G ratio was also determined. They varied from $34 / 66$ to $76 / 24$, but it was not possible to find any correlation between the ratio and the deviations of the 
total protein as estimated by $\mathrm{Kjeldahl}$ nitrogen determinations and specific gravity. This might have been expected, since Nugent and Towle (9) separated albumin from globulin and found their effect on specific gravity to be the same.

\section{The effect of variations in the nonprotein solids}

Since the protein content of serum is between 75 and 80 per cent of the dry weight, a close correlation with specific gravity is to be expected. The remainder of the total solid content is composed of a number of constituents each of which is measured in milligrams per $100 \mathrm{cc}$. The most important of these with regard to specific gravity and protein correlation appear to be fat and cholesterol. We have had 10 specimens in which the cholesterol values were known to be over 200 mgm. per cent. The results are shown in Table I.

TABLE I

Effect of variations in cholesterol content

\begin{tabular}{|c|c|c|c|c|}
\hline \multirow{2}{*}{ Specimen } & \multirow{2}{*}{ Cholesterol } & \multicolumn{2}{|c|}{ Total protein } & \multirow{2}{*}{$\underset{\substack{\text { Devia- } \\
\text { tion }}}{\text {. }}$} \\
\hline & & $\underset{\text { method }}{\text { Kjeldahl }}$ & $\begin{array}{l}\text { Falling drop } \\
\text { method }\end{array}$ & \\
\hline \multirow{3}{*}{ Serum } & $\underset{\text { per cent }}{\operatorname{mgm} .}$ & $\underset{\text { per cent }}{\text { grams }}$ & $\underset{\text { per cent }}{\text { grams }}$ & $\underset{\substack{\text { grams } \\
\text { per cent }}}{\text {. }}$ \\
\hline & $\begin{array}{l}289 \\
315 \\
358 \\
664 \\
812\end{array}$ & $\begin{array}{l}4.19 \\
6.98 \\
6.82 \\
4.82 \\
4.76\end{array}$ & $\begin{array}{l}4.20 \\
7.18 \\
6.98 \\
5.01 \\
5.17\end{array}$ & $\begin{array}{r}+0.01 \\
+0.20 \\
+0.13 \\
+0.19 \\
+0.41\end{array}$ \\
\hline & $\begin{array}{l}266 \\
289 \\
315 \\
333 \\
789\end{array}$ & $\begin{array}{l}6.57 \\
4.19 \\
6.77 \\
6.77 \\
4.85\end{array}$ & $\begin{array}{l}6.87 \\
4.05 \\
6.85 \\
7.15 \\
5.36\end{array}$ & $\begin{array}{r}+0.30 \\
-0.14 \\
+0.08 \\
+0.38 \\
+0.51\end{array}$ \\
\hline
\end{tabular}

It does not appear that moderate elevations in cholesterol content affect the usefulness of the method. Most specimens with high cholesterol also have high fat content and this probably counterbalances the effect of cholesterol on specific gravity.

On 29 specimens, the chloride content ranged from 84.4 to 108.6 m.eq., but no correlation with the deviation between the specific gravity and Kjeldahl estimates of protein was apparent.

\section{A comparison of serum with oxalated plasma and heparinized plasma}

Blood drawn from 3 patients was used in this experiment. From blood which was taken at one
TABLE II

A comparison of serum with heparinized and oxalated plasma

\begin{tabular}{|c|c|c|c|c|c|c|}
\hline \multirow{2}{*}{$\underset{\text { jubt }}{\text { Sub- }}$} & \multirow[b]{2}{*}{ Specimen } & \multirow{2}{*}{$\begin{array}{l}\text { Formula: } \\
\text { Total } \\
\text { protein }=\end{array}$} & \multirow{2}{*}{$\begin{array}{c}\text { Spe- } \\
\text { cific } \\
\text { grav- } \\
\text { ity }\end{array}$} & \multicolumn{3}{|c|}{ Total protein } \\
\hline & & & & $\begin{array}{c}\text { Spe- } \\
\text { cific } \\
\text { grav- } \\
\text { ity }\end{array}$ & $\begin{array}{l}\text { Kjel- } \\
\text { dahl }\end{array}$ & $\begin{array}{l}\text { Re- } \\
\text { frac- } \\
\text { tive } \\
\text { index }\end{array}$ \\
\hline & & & & $\begin{array}{c}\text { grams } \\
\text { per } \\
\text { cent }\end{array}$ & $\begin{array}{l}\text { grams } \\
\text { per } \\
\text { cent }\end{array}$ & $\begin{array}{l}\text { grams } \\
\text { per } \\
\text { cent }\end{array}$ \\
\hline \multirow[t]{2}{*}{ M.T. } & Serum & $\begin{array}{l}345(G-1.0076) \\
340(G-1.0099)\end{array}$ & $\begin{array}{l}1.0220 \\
1.0234\end{array}$ & $\begin{array}{l}4.97 \\
4.59\end{array}$ & $\begin{array}{l}4.66 \\
4.63\end{array}$ & $\begin{array}{l}4.00 \\
4.00\end{array}$ \\
\hline & plasma & $343(G-1.0070)$ & 1.0221 & 5.18 & 4.82 & 4.00 \\
\hline \multirow[t]{2}{*}{ H.H. } & $\begin{array}{l}\text { Serum } \\
\text { Oxalated plasma } \\
\text { Heparinized }\end{array}$ & & $\begin{array}{l}1.0261 \\
1.0268\end{array}$ & $\begin{array}{l}6.38 \\
5.75\end{array}$ & $\begin{array}{l}6.11 \\
6.06\end{array}$ & $\begin{array}{l}6.30 \\
5.90\end{array}$ \\
\hline & plasma & & 1.0272 & 6.93 & 6.71 & 6.50 \\
\hline \multirow[t]{2}{*}{ G.J. } & Serum & & $\begin{array}{l}1.0287 \\
1.0310\end{array}$ & $\begin{array}{l}7.28 \\
7.17\end{array}$ & $\begin{array}{l}7.21 \\
7.12\end{array}$ & $\begin{array}{l}6.90 \\
6.90\end{array}$ \\
\hline & $\begin{array}{l}\text { Heparinued } \\
\text { plasma }\end{array}$ & & 1.0297 & 7.79 & 7.56 & 7.00 \\
\hline
\end{tabular}

venepuncture into a single syringe, serum, heparinized plasma, and oxalated plasma were prepared. The total protein was estimated by Kjeldahl, specific gravity, and refractometry. The specific gravity was determined in all cases by the falling drop method. The total protein of heparinized plasma was estimated from the specific gravity by the formula of Moore and Van Slyke (2). In all three cases, the oxalated specimens contained the lowest protein content and the heparinized plasma the highest. In one instance, the total protein content of the oxalated specimen differed from the heparinized specimen by 0.65 gram per cent according to the macro-Kjeldahl method. Heparinized plasma contained an average of 0.4 gram per cent more protein than serum because it contains fibrinogen. The low values with oxalate are probably due to the withdrawal of water from the cells.

\section{DISCUSSION}

Rowe (10) and others have found that stasis during the withdrawal of blood from the patient, with pressure intermediate between venous and arterial, causes in one minute an increase of 0.17 gram per $100 \mathrm{cc}$. in the protein content of plasma due to loss of water from the blood vessels. In ordinary clinical routine, no distinction is made between values obtained from plasma or serum, yet it has been shown that oxalated plasma may contain 0.3 to 0.4 gram per cent less protein than serum (11) and heparinized plasma may contain as much as 0.65 gram per cent more protein than oxalated plasma. No matter what method is used 
to estimate the protein content of a specimen, its accuracy with regard to clinical application will depend for the greater part on the manner in which it is collected and on the way it is prepared.

\section{SUMMARY}

A new method for the estimation of total serum or plasma protein is presented. It is based upon the linear relationship which exists between the specific gravity and the protein content. The specific gravity is determined by a new falling drop method which is easy, time saving, and can be done with extremely small quantities of blood. It provides a measure of the protein content with an accuracy which exceeds clinical requirements, and is about twice as accurate as the refractometric method.

\section{BIBLIOGRAPHY}

1. Peters, J. P., and Van Slyke, D. D., Quantitative Clinical Chemistry. Vol. II. Methods. Williams and Wilkins Co., Baltimore, 1932.

2. Moore, N. S., and Van Slyke, D. D., The relationships between plasma specific gravity, plasma protein content and edema in nephritis. J. Clin. Invest., 1930, 8, 337.
3. Zozaya, J., A physicochemical study of blood sera. J. Biol. Chem., 1935, 110, 599.

4. Weech, A. A., Reeves, E. B., and Goettsch, E., The relationship between specific gravity and protein content in plasma, serum, and transudate from dogs. J. Biol. Chem., 1935, 113, 167.

5. Barbour, H. G., and Hamilton, W. F., The falling drop method for determining specific gravity. J. Biol. Chem., 1926, 69, 625.

6. Johnson, A. H., and Green, J. R., Modified methyl red and sodium alizarin sulfonate indicators. Ind. and Eng. Chem., Anal. Ed., 1930, $2,2$.

7. Pearl, R., Medical Biometry and Statistics. W. B. Saunders Co., Philadelphia, 1923.

8. Sackett, G. E., Modification of Bloor's method for the determination of cholesterol in whole blood or blood serum. J. Biol. Chem., 1925, 64, 203.

9. Nugent, R. L., and Towle, L. W., The specific gravity of synthetic solutions of serum albumin and serum globulin. J. Biol. Chem., 1934, 104, 395.

10. Rowe, A. H., The effect of venous stasis on the proteins of human blood serum. J. Lab. and Clin. Med., 1915-1916, 1, 485.

11. Peters, J. P., Eisenman, A. J., and Bulger, H. A., The plasma proteins in relation to blood hydration. J. Clin. Invest., 1925, 1, 435.

12. Kagan, B. M., A simple method for the estimation of total protein content of plasma and serum. I. A falling drop method for the determination of specific gravity. J. Clin. Invest., 1938, 17, 369. 